\title{
Overweightness and obesity prevalence among university students in 2015-2016 educational season
}

\author{
Eren Uluöz ${ }^{1}$
}

\begin{abstract}
The main purpose of this study is to find out the obesity prevalence among university students. In addition to the main purpose, another aims of this study is to determine the individual features of participants related to obesity such as gender, age, being an obese in family and doing physical activity.

This study was performed on university students from five different faculties of Çukurova University in 2015-2016 educational season. In this study, 894 volunteer students accepted for attending to the research. The mean age of female participants was $21.39 \pm 2.53$ years. However, mean of males was $22.28 \pm 2.73$ years. Descriptive study design and causal comparative methods were used. The individual information form created by the researcher was used to determine the demographic characteristics of the participants. BMI was analyzed both quantitative and categorical ways in this study. WHO's classification method was used for categorizing of BMI. All findings in the study were summarized by descriptive statistical methods such as mean, standard deviation, frequency, percentage, etc. The independent sample T test, the ANOVA test, Pearson correlation test and chi-square test were used. In all analyzes, significance level was accepted as $\mathrm{p}$ $<0.05$.

The mean of the BMI was calculated as $22.40 \pm 3.49 \mathrm{~kg} / \mathrm{m}^{2}$. There was a statistically significant difference between the mean BMI of males $\left(23.80 \pm 3.40 \mathrm{~kg} / \mathrm{m}^{2}\right)$ and female participants $\left(21,01 \pm 2,99 \mathrm{~kg} / \mathrm{m}^{2}, \mathrm{t}(-13,043)=892, \mathrm{p}<0.05\right)$. Also, it was found statically significant difference among BMI classification groups for gender (obesity rate of male: $4.9 \%$; female: $1.1 \%), \mathrm{x}^{2}(\mathrm{df}=3$, $\mathrm{n}=894)=101.21, \mathrm{p}<0.05$. These results have indicated that the rate of obesity among university students is lower than normal population in Turkey. At the same time the findings of this study have shown similar characteristics with the university students' of other countries reported by previous studies.

In conclusion, it should be taken some measures for reducing overweightness and obesity such as increasing physical activity possibilities for people in all condition by local and central Governments, increasing the number of hours of physical education and sports lessons in schools as much as possible and the processing of these courses must be inspected strongly, more strict measures taken by the government to reduce obesity rates in society, informing and awareness of community on obesity, informing adequate and balanced nutrition by using the all media devices and facilities.
\end{abstract}

Keywords: Obesity; overweight; University Students; BMI; Health.

\footnotetext{
1 Ph.D. Lecturer, Çukurova University, School of Physical Education and Sports, Department of Training, euluoz@cu.edu.tr
} 


\section{Introduction}

Obesity is one of the most common health problems all over the word. World Health Organization (WHO) reported that worldwide obesity prevalence has more than doubled since 1980. Furthermore, in 2014, more than 1.9 billion adults in which 18 years and older were overweight. Over 600 million of this population was obese. Thirty nine percent of adults aged 18 years and over were overweight in 2014, and 13\% were obese. Forty one million children under the age of 5 were overweight or obese in 2014. WHO has claimed that obesity is a preventable health problem. (WHO media center, 2016).

Obesity is a chronic disease that is characterized by unbalanced nutrition condition due to excessive and incorrect eating habits. In accordance with these facts, numerous risk factors have been reported related to overweightness and obesity (Avenell et al, 2004; Fogelholm et al, 2010; Mokdad et al, 2003; Moreno and Rodriguez). The major risks and the influencing factors are listed below;
- Age
- Gender
- Genetic factors
- Excessive and incorrect eating habits
- Insufficient physical activity
- Level of education
- Socio-cultural factors
- Financial status
- Hormonal factors
- Metabolic factors
- Psychological problems
- Repetitive very low energy diets
- Using of alcohol
- Using some medications (antidepressants, etc.)
- Number of births and time between births

Obesity is an important health problem that can lead to various disorders and even deaths by affecting all organs and systems of the body, especially cardiovascular and endocrine system (WHO, 1998). Furthermore, obesity causes various health disorders. Investigation of the diseases related to overweight and obesity are the most popular research subject in recent years. Numerous researchers have strived to define obesity-related diseases (Cancello and Clement, 2006; Cheung and Wong, 2007; Eckel et al, 2002; Hersoug and Linneberg, 2007; Kalan and Yeşil, 2010; Must et al, 1999; Özdel et al, 2011). Most of the diseases have a strong relationship with obesity. The most common diseases are given below $(\mathrm{NIH}, 2012)$;

- Coronary heart disease

- High blood pressure

- Stroke

- Type 2 diabetes

- Abnormal blood fats

- Metabolic syndrome

- Cancer (colon, uterus, prostate, breast, endometrial, and gallbladder cancers)

- Osteoarthritis

- Sleep apnea 
- Obesity hypoventilation syndrome

- Reproductive problems

- Gallstones

- Muscle-skeletal disorders

- Respiratory problems

- Hypertension

- Fat and cholesterol increase in blood

- Inflammatory diseases and stone

- Decreased fertility

- Menstrual irregularities

- Emotional stress

- Social exclusion

- Social obsession

- Self-obsession

Body mass index (BMI) is the major standard to diagnose the obesity. BMI standard is used for the identification and classification of body structure. According to a form determined by the WHO, BMI - the weight in kilograms divided by the square of the height in meters $(\mathrm{kg} / \mathrm{m} 2)$ - is a commonly used index for classifying overweight and obesity in adults or all age groups. WHO defines overweight as a BMI equal to or more than $25 \mathrm{~kg} / \mathrm{m}^{2}$, and obesity as a BMI equal to or more than $30 \mathrm{~kg} / \mathrm{m}^{2}$. The classification of obesity is shown in Figure 1 (WHO, 1997).

Figure 1. BMI Classification of WHO

\begin{tabular}{||c|l|}
\hline \multicolumn{2}{|c|}{ BMI classification } \\
\hline Underweight & $<18.5$ \\
\hline Normal range & $18.5-24.9$ \\
\hline Overweight & $\geqslant 25.0$ \\
\hline Preobese & $25.0-29.9$ \\
\hline Obese & $\geqslant 30.0$ \\
\hline Obese class I & $30.0-34.9$ \\
\hline Obese class II & $35.0-39.9$ \\
\hline Obese class III & $\geqslant 40.0$ \\
\hline
\end{tabular}

Obesity is accepted as one of the most important health problem for people all over the world by WHO. General information of obesity has been updated regularly by WHO in its own official web pages. These explanations are given Figure 2. 
Uluöz, E. (2016). Overweightness and obesity prevalence among university students in 2015-2016 educational season. Journal of Human Sciences, 13(3), 5884-5900. doi:10.14687/jhs.v13i3.4293

\section{Figure 2. General information of obesity (WHO, 2016)}

\section{WHO has given these general information for obesity}

- Overweight and obesity are defined as "abnormal or excessive fat accumulation that may impair health": Body mass index (BMI) - the weight in kilograms divided by the square of the height in meters $(\mathrm{kg} / \mathrm{m} 2)$ is a commonly used index to classify orerweight and obesity in adults. WHO defines orenweight as a BMI equal to or more than 25 , and obesity as a BMI equal to or more than 30 .

- In 2008, more than 1.4 billion adults were overweight and more than half a billion were obese. At least 2.8 million people each year die as a result of being orerweight or obese. The prevalence of obesity has nearly doubled between 1980 and 2008 . Once associated with high-income countries, obesity is now also prevalent in low- and middle-income countries.

- Globally, 42 million preschool children were overweight in 2013: Childhood obesity is one of the most serious public health challenges of the 21 st century. Orerweight children are likely to become obese adults. They are more likely than non-orerweight children to develop diabetes and cardiovascular diseases at a younger age, which in turn are associated with a higher chance of premature death and disability.

- Overweight and obesity are linked to more deaths worldwide than underweight: $65 \%$ of the world's population lives in a country where overweight and obesity kills more people than underweight. This includes all high-income and middle-income countries. Globally, $44 \%$ of diabetes, $23 \%$ of ischemic heart disease and $7-41 \%$ of certain cancers are attributable to overweight and obesity.

- For an individual, obesity is usually the result of an imbalance between calories consumed and calories expended: An increased consumption of highly calorific foods, without an equal increase in phrsical activity, leads to an unhealthy increase in weight. Decreased levels of physical activity will also result in an energy imbalance and lead to weight gain.

- Supportive environments and communities are fundamental in shaping people's choices and preventing obesity: Individual responsibility can only have its full effect where people have access to a healthry lifestrle, and are supported to make healthy choices. IVHO mobilizes the range of stakeholders who have rital roles to play in shaping healthry environments and making healthier diet options affordable and easily accessible.

- Children's choices, diet and phrsical activity habits are influenced by their surrounding environment: Social and economic development as well as policies in the areas of agriculture, transport, urban planning, environment, education, food processing, distribution and marketing influence children's dietary habits and preferences as well as their physical activity patterns. Increasingly, these influences are promoting unhealthy wreight gain leading to a steady rise in the prevalence of childhood obesity.

- Eating a healthy diet can help prevent obesity: People can: "maintain a healthy weight", "limit total fat intake and shift fat consumption away from saturated fats to unsaturated fats", "increase consumption of fruit, regetables, pulses, whole grains and nuts", "limit the intake of sugar and salt".

- Regular phryical activity helps maintain a healthy body: People should engage in adequate levels of phrsical actirity throughout their lives. At least 30 minutes of regular, moderate-intensity phrsical actirity on most days reduces the risk of cardiovascular disease, diabetes, colon cancer and breast cancer. Muscle strengthening and balance training can reduce falls and improve mobility among older adults. More activity may be required for weight control.

- Curbing the global obesity epidemic requires a population-based multi-sectoral, multi-disciplinary, and culturally relevant approach: WHO's Action Plan for the Global Strategy for the Prevention and Control of Non-communicable Diseases provides a roadmap to establish and strengthen initiatives for the surveillance, prevention and management of non-communicable diseases, including obesity.

Obesity prevalence shows various results among different population in the world. For example, Wang and Beydoun (2007) reported that obesity prevalence increased from $13 \%$ to $32 \%$ between the 1960s and 2004 among adults and $66 \%$ of adults are overweight or obese; $16 \%$ of children and adolescents are overweight and 34\% are at risk of overweight in United States. They have claimed that by $2015,75 \%$ of adults will be overweight or obese, and $41 \%$ will be obese. On 
Uluöz, E. (2016). Overweightness and obesity prevalence among university students in 2015-2016 educational season. Journal of Human Sciences, 13(3), 5884-5900. doi:10.14687/jhs.v13i3.4293

the other hand, Steyn et al (1998) found out that the prevalence of underweight in men was 19\% and in women $3.7 \% ; 22 \%$ of the men were overweight and $7.9 \%$ obese, while $36.4 \%$ of women were overweight and $34.4 \%$ obese in an African sample. Brown et al (2007) focused on the rate of obesity in Australia and they reported the prevalence of obesity was 16,2\% (men: 16,6\%, women: 15,8\% / age: $18+$ ). Similarly, Vanasse et al (2003) found out 15,2\% obesity rate for Canadian population (age: $20+$ ). Although the rates of overweightness or obesity of Turkish population are relatively lower in comparison with developed societies such as United States, Australia and European countries, it is reported that prevalence of obesity have increased day by day in recent years in Turkey. For example, in Turkey, the incidence of obesity in children has increased from 6$7 \%$ to $15-16 \%$ in the last 20 years (TC Sağlık Bakanlığ1/Ministry of Health, 2010). Although there are four major studies (Heart Disease and Risk Factor Study in Adults in Turkey (TEKHARF), Turkey Obesity and Hypertension Research (TOHTA), Turkey Diabetes, Obesity and Hypertension Epidemiology (TURDEP) and TOAD-Turkey Obesity Profiling Study) that investigate a wide range of subjects related to the prevalence of obesity in adults in Turkey, there is a few studies performed on university students.

In this context, the main purpose of this study is to find out the obesity prevalence among university students. In addition to the main purpose, another aims of this study is to determine the individual features of participants related to obesity such as gender, age, being an obese in family and doing physical activity.

\section{Materials and Methods}

This study was performed on university students from five different faculties of Çukurova University in 2015-2016 educational season. In this study, 894 students accepted attending to the study. Some demographic characteristics of the participants are given Table 1 and Table 2.

Table 1. The age variables of participants attending to the study

\begin{tabular}{llccccc}
\hline & & $\mathrm{n}$ & $\min$ & $\max$ & mean & s.d. \\
\hline \multirow{4}{*}{ Age } & Female & 447 & 16,00 & 48.00 & 21.39 & 2.53 \\
& Male & 447 & 17,00 & 45.00 & 22.28 & 2.73 \\
& Total & 894 & 16,00 & 48.00 & 21.84 & 2.67 \\
\hline
\end{tabular}

The mean age of female participants was $21.39 \pm 2.53$ years. However, mean age of males was $22.28 \pm 2.73$ years. Distribution of participants in terms of gender, faculties and classes are given Table 2.

Table 2. Distributions of participant in terms of gender, faculties and classes

\begin{tabular}{llll}
\hline \multirow{3}{*}{ Gender } & & $\mathrm{f}$ & $\%$ \\
& Female & 447 & 50.0 \\
& Male & 447 & 50.0 \\
& Total & 894 & 100.0 \\
\hline \multirow{5}{*}{ Faculties } & The School of Physical Education and Sports & 109 & 12.2 \\
& Engineering and Architecture Faculty & 194 & 21.7 \\
& Health Sciences Faculty & 196 & 21.9 \\
& Economics and Administrative Sciences Faculty & 201 & 22.5 \\
& The Faculty of Education & 194 & 21.7 \\
& Total & 894 & 100.0 \\
\hline \multirow{5}{*}{ Classes } & 1. classes & 219 & 24.5 \\
& 2. classes & 248 & 27.7 \\
& 3. classes & 229 & 25.6 \\
& 4. classes & 198 & 22.1 \\
& Total & 894 & 100.0 \\
\hline
\end{tabular}


Uluöz, E. (2016). Overweightness and obesity prevalence among university students in 2015-2016 educational season. Journal of Human Sciences, 13(3), 5884-5900. doi:10.14687/jhs.v13i3.4293

The distribution of female and male participants is the same as 50\%. School of Physical Education and Sports (109 participants), Engineering and Architecture Faculty (194 participants), Health Sciences Faculty (196 participants), Economics and Administrative Sciences Faculty (201 participants) and Faculty of Education (194 participants) hosted to this study with 894 students totally.

Descriptive study design and causal comparative methods were used in this study. Cohen\&Manion, (1994) reported that there were at least two groups exposed to the same conditions in different ways, or different groups exposed and not exposed for causal comparative method. These groups are examined from the perspective of some variables in order to reveal the possible causes and influences of this present situation.

In this study, the individual information form created by the researcher was used to determine the demographic characteristics of the participants. The explanatory information related to the study has been given by the researcher on the purpose and importance of researching to the participants in the classroom environment. Necessary explanations have been given to the participants that the findings to be obtained in the research will be presented only as quantitative results after being processed by statistical methods and also individual information will not be included with certainty and that the results of the research will not be used except for the stated purposes. As a result of these explanations, students who stated that they did not want to participate in the study were excluded from the classroom environment and taken out of the classroom environment and data collection instruments were applied to students who volunteered to participate in the study. Before the participants began to fill in the data collection tools, necessary explanations were made on the importance of the scientific research and requested answering to read the questions carefully and give the correct answers as much as possible.

BMI was analyzed both quantitative and categorical ways in this study. WHO's classification method was used for the classifying BMI. On the other hand all of the three obese groups (class I, Class II, Class II) defined by WHO (see figure 1) was transformed as a single group for statistical analyses. All findings were summarized by statistical methods such as mean, standard deviation, frequency, percentage, etc. The independent sample $T$ test, one of the parametric hypothesis tests, was used to test the significance of the mean differences of the two group independent variables in the study. The ANOVA test was used to test the significance of the mean differences between groups when the number of groups was higher than double. Pearson correlation test was used to determine the relationship between continuous numerical variables. (Büyüköztürk, 2012). In all analyzes, statically significance level was accepted as p <0.05.

\section{Results}

The findings of this study are given in this part of the paper. All variables are summarized by descriptive statistics techniques such as mean, standard deviation, frequency and percentage. Table 3 and Table 4 show general descriptive statistic results of participants.

Table 3. Physical measurement results of participants

\begin{tabular}{llllll}
\hline & $\mathrm{n}$ & $\min$ & $\max$ & mean & s.d. \\
\hline Weight & 894 & 39.00 & 130 & 66.48 & 14.37 \\
Height & 894 & 145.00 & 210 & 171.59 & 9.54 \\
BMI & 894 & 14.69 & 39.54 & 22.40 & 3.49 \\
\hline
\end{tabular}

The mean weight of the participants was $66.48 \pm 14.37 \mathrm{~kg}$. (min:39 kg., max: $130 \mathrm{~kg}$.). However the height mean of the participants was found as $171.59 \pm 9.54 \mathrm{~cm}$. (min: $145 \mathrm{~cm}$., max: $210 \mathrm{~cm}$.). According as weight and height findings, the mean of the BMI was calculated as 
Uluöz, E. (2016). Overweightness and obesity prevalence among university students in 2015-2016 educational season. Journal of Human Sciences, 13(3), 5884-5900. doi:10.14687/jhs.v13i3.4293

$22.40 \pm 3.49 \mathrm{~kg} / \mathrm{m}^{2}$ (min: $14.69 \mathrm{~kg} / \mathrm{m}^{2}$, max: $39.54 \mathrm{~kg} / \mathrm{m}^{2}$ ). Table 4 demonstrates the distribution of BMI classification of the participants.

Table 4. Distribution of BMI classification of the participants

\begin{tabular}{lcc}
\hline BMI classification & $\mathrm{f}$ & $\%$ \\
\hline 1. Underweight & 86 & 9.6 \\
2. Normal weight & 646 & 72.3 \\
3. Overweight & 135 & 15.1 \\
4. Class I obesity & 21 & 2.3 \\
5. Class II obesity & 6 & 0.7 \\
6. Class III obesity & 0 & 0.0 \\
Total & 894 & 100.0 \\
\hline
\end{tabular}

The most common group of the BMI classification of this study was the second group (normal weight: 646 participants) with the rate of $72.3 \%$. The rate of overweight participants was found as $15.1 \%$. Similarly, 9.6\% of the participants were taken placed in underweight groups. Class I obese groups had $2.3 \%$ of rate. On the other hand Class II groups and Class III groups had lower rates, $0.7 \%$ and $0.0 \%$, respectively. The result of the independent $\mathrm{T}$ test result of comparison $\mathrm{BMI}$ scores in terms of gender is given Table 5 .

Table 5. Independent $T$ test result of comparison BMI scores in terms of gender

\begin{tabular}{lcccccc}
\hline Gender & & mean & Sd & df & t & $\mathrm{p}$ \\
\hline Female & 447 & 21.01 & 2.99 & & & \\
Male & 447 & 23.80 & 3.40 & 892 & -13.043 & $\mathbf{0 . 0 0 *}^{*}$ \\
\hline $\boldsymbol{p}<\mathbf{0 . 0 \mathbf { 0 } ^ { * }}$ & & & & & &
\end{tabular}

There was a statistically significant difference between the mean BMI of male and female participants, $\mathrm{t}(-13.043)=892, \mathrm{p}<0.05$. Table 6 shows Chi square test results of BMI classification comparison in terms of gender.

Table 6. Chi square test results of BMI classification comparison in terms of gender

\begin{tabular}{|c|c|c|c|c|c|c|c|}
\hline & & Underweight & Normal weight & Overweight & Obese & $\mathrm{x}^{2} \quad \mathrm{df}$ & $\mathrm{p}$ \\
\hline \multirow[b]{2}{*}{ Female } & $\mathrm{n}$ & 75 & 337 & 30 & 5 & \multirow{6}{*}{101.213} & \multirow{6}{*}{$0.00^{*}$} \\
\hline & $\%$ & $16.8 \%$ & $75.4 \%$ & $6.7 \%$ & $1.1 \%$ & & \\
\hline \multirow{3}{*}{ Male } & $\mathrm{n}$ & 11 & 309 & 105 & 22 & & \\
\hline & $\%$ & $2.5 \%$ & $69.1 \%$ & $23.5 \%$ & $4.9 \%$ & & \\
\hline & $\mathrm{n}$ & 86 & 646 & 135 & 27 & & \\
\hline Total & $\%$ & $9.6 \%$ & $72.3 \%$ & $15.1 \%$ & $3.0 \%$ & & \\
\hline
\end{tabular}

It was found significant differences among BMI classification groups for gender, $x^{2}(d f=3$, $\mathrm{n}=894)=101.21, \mathrm{p}<0.05$. The result of correlation between age and BMI is given figure 3 . 
Figure 3. Correlation graphs of age and BMI

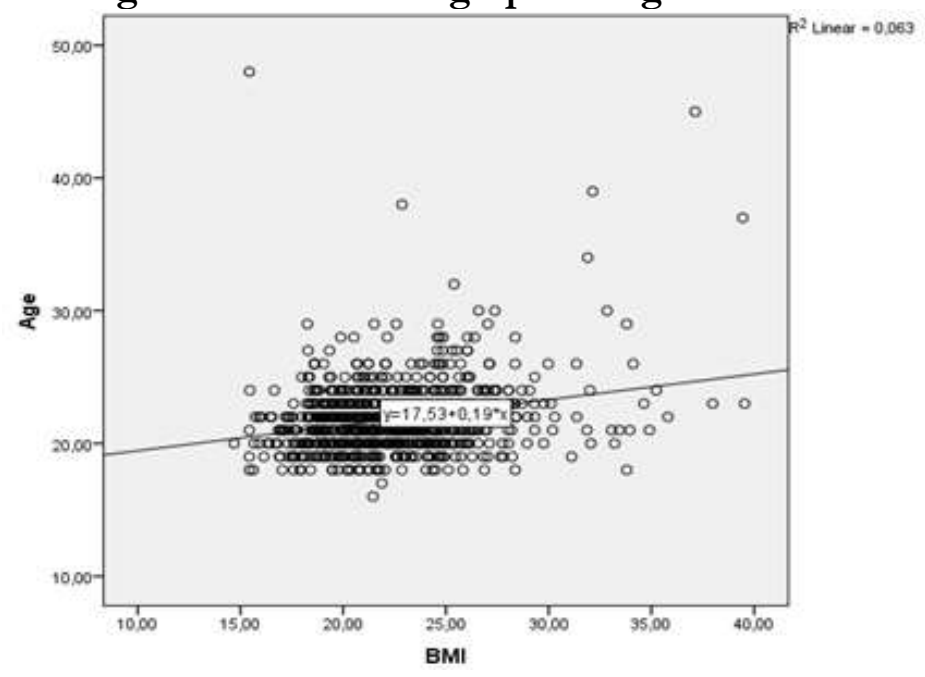

The result of the Pearson correlation test between age and BMI demonstrated a weak and positive relationship, $\mathrm{r}=0.252, \mathrm{p}<0.05$. Descriptive statistic and ANOVA test results of age in terms of BMI classification are presented Table 7.

Table 7. Descriptive statistic and ANOVA test results of ages in terms of BMI classification

\begin{tabular}{llllll}
\hline BMI classification & $\mathrm{n}$ & $\min$ & $\max$ & $\operatorname{mean}$ & s.d. \\
\hline Underweight & 86 & 18,00 & 48,00 & 21,23 & 3,54 \\
Normal weight & 646 & 16,00 & 38,00 & 21,67 & 2,76 \\
Overweight & 135 & 18,00 & 32,00 & 22,60 & 2,58 \\
Obese & 27 & 18,00 & 45,00 & 25,00 & 6,62 \\
Total & 894 & 16,00 & 70,00 & 21,87 & 3,07
\end{tabular}

\begin{tabular}{lllllll}
\hline & $\begin{array}{l}\text { Sum of } \\
\text { squares }\end{array}$ & df & $\begin{array}{l}\text { Mean } \\
\text { square }\end{array}$ & f & p & Significant differences \\
\hline $\begin{array}{l}\text { Between } \\
\text { Groups }\end{array}$ & 396.649 & 3 & 132.216 & & & \\
$\begin{array}{l}\text { Within } \\
\text { Groups }\end{array}$ & 8042.569 & 890 & 9.037 & 14.631 & $\mathbf{0 . 0 0 *}$ & $\begin{array}{l}\text { underweight - overweight, obese } \\
\text { normal weight- overweight, obese }\end{array}$ \\
Total & 8439.218 & 893 & & & & \\
\hline $\boldsymbol{p < 0 . 0 \mathbf { 0 5 } ^ { * }}$ & & & & & & \\
\hline
\end{tabular}

A one-way between groups analysis of variance was conducted to determine the differences among four BMI classification groups in age variable. Results derived from one-way ANOVA demonstrated that, there were statistically significant differences at the $\mathrm{p}<0.05$ level in BMI scores for the four BMI classification groups in age results, $\mathrm{F}(3,890)=14.631, \mathrm{p}=0.05$. Independent $\mathrm{T}$ test result of comparison of BMI in terms of being an obese in family is demonstrated Table 8. 
Uluöz, E. (2016). Overweightness and obesity prevalence among university students in 2015-2016 educational season. Journal of Human Sciences, 13(3), 5884-5900. doi:10.14687/ihs.v13i3.4293

Table 8. Independent $T$ test result of comparison of BMI in terms of being an obese in family

\begin{tabular}{|c|c|c|c|c|c|c|}
\hline $\begin{array}{l}\text { Being an obese } \\
\text { in family }\end{array}$ & $\mathrm{n}$ & mean & $\mathrm{Sd}$ & $\overline{d f}$ & $\mathrm{t}$ & $p$ \\
\hline \multirow[t]{2}{*}{ Yes } & 122 & 23.86 & 4.46 & & & \\
\hline & & & & 892 & 5.035 & $0.00 *$ \\
\hline No & 772 & 22.17 & 3.25 & & & \\
\hline
\end{tabular}

A statistically significant difference was found between the mean BMI of having an obese person in own family or not groups, $\mathrm{t}(5.035)=892, \mathrm{p}<0.05$. Chi square test result of BMI classification comparison in terms of whether being an obese in family is shown in Table 9.

Table 9. Chi square test result of BMI classification comparison in terms of being an obese in family or not

\begin{tabular}{|c|c|c|c|c|c|c|}
\hline & & \multicolumn{2}{|c|}{ Being an obese in family } & \multirow[t]{2}{*}{$x^{2}$} & \multirow[t]{2}{*}{ df } & \multirow[t]{2}{*}{$\mathrm{p}$} \\
\hline & & yes & no & & & \\
\hline \multirow{2}{*}{ Underweight } & $\mathrm{n}$ & 7 & 79 & \multirow{10}{*}{30.090} & \multirow{10}{*}{3} & \multirow{10}{*}{$0.00 *$} \\
\hline & $\%$ & $8.1 \%$ & $91.9 \%$ & & & \\
\hline \multirow{2}{*}{$\begin{array}{l}\text { Normal } \\
\text { weight }\end{array}$} & $\mathrm{n}$ & 74 & 572 & & & \\
\hline & $\%$ & $11.5 \%$ & $88.5 \%$ & & & \\
\hline \multirow{2}{*}{ Overweight } & $\mathrm{n}$ & 30 & 105 & & & \\
\hline & $\%$ & $22.2 \%$ & $77.8 \%$ & & & \\
\hline \multirow{2}{*}{ Obese } & $\mathrm{n}$ & 11 & 16 & & & \\
\hline & $\%$ & $40.7 \%$ & $59.3 \%$ & & & \\
\hline \multirow{2}{*}{ Total } & $\mathrm{n}$ & 122 & 772 & & & \\
\hline & $\%$ & $13.6 \%$ & $86.4 \%$ & & & \\
\hline
\end{tabular}

There was a highly significant difference among BMI classification groups for having an obese person in own family or not groups, $\mathrm{x}^{2}(\mathrm{df}=3, \mathrm{n}=894)=30.090, \mathrm{p}<0.05$. Independent $\mathrm{T}$ test result of comparison of BMI scores in terms of doing physical activity is given Table 10.

Table 10 . Independent $T$ test result of comparison of BMI scores in terms of doing physical activity (regularly)

\begin{tabular}{lcccccc}
\hline \multicolumn{2}{l}{ Doing physical activity } & mean & Sd & df & t & p \\
\hline Yes & 546 & 22.38 & 2.97 & & & \\
No & 348 & 22.43 & 4.18 & 892 & -0.204 & 0.839 \\
\hline
\end{tabular}

A statistically significant difference was not found between the mean body mass indexes of doing physical activity or not groups, $\mathrm{t}(-0.204)=892, \mathrm{p}>0.05$. Chi square test result of BMI classification comparison in terms of whether doing physical activity is shown in Table 11. 
Uluöz, E. (2016). Overweightness and obesity prevalence among university students in 2015-2016 educational season. Journal of Human Sciences, 13(3), 5884-5900. doi:10.14687/ihs.v13i3.4293

Table 11. Chi square test result of BMI classification comparison in terms of doing physical activity (regularly)

\begin{tabular}{|c|c|c|c|c|c|c|}
\hline & \multicolumn{3}{|c|}{ Doing physical activity (regularly) } & \multirow[b]{2}{*}{$x^{2}$} & \multirow[b]{2}{*}{ df } & \multirow[b]{2}{*}{$\mathrm{p}$} \\
\hline & & yes & no & & & \\
\hline \multirow{2}{*}{ Underweight } & $\mathrm{n}$ & 40 & 46 & \multirow{7}{*}{18.887} & \multirow{7}{*}{3} & \multirow{7}{*}{$0.00 *$} \\
\hline & $\%$ & $46.5 \%$ & $53.5 \%$ & & & \\
\hline Normal weight & $\mathrm{n}$ & 414 & 232 & & & \\
\hline & $\%$ & $64.1 \%$ & $35.9 \%$ & & & \\
\hline Overweight & $\begin{array}{l}\mathrm{n} \\
\%\end{array}$ & $\begin{array}{c}83 \\
61.5 \% \\
\end{array}$ & $\begin{array}{c}52 \\
38.5 \%\end{array}$ & & & \\
\hline Obese & $\begin{array}{l}\mathrm{n} \\
\%\end{array}$ & $\begin{array}{c}9 \\
33.3 \%\end{array}$ & $\begin{array}{c}18 \\
66.7 \%\end{array}$ & & & \\
\hline Total & $\begin{array}{l}\mathrm{n} \\
\%\end{array}$ & $\begin{array}{c}546 \\
61.1 \%\end{array}$ & $\begin{array}{c}348 \\
38.9 \%\end{array}$ & & & \\
\hline
\end{tabular}

$p<0.05^{*}$

There was a highly significant difference among BMI classification groups for doing physical activity or not groups, $\mathrm{x}^{2}(\mathrm{df}=3, \mathrm{n}=894)=18.887, \mathrm{p}<0.05$.

\section{Discussion}

In this study the mean of the BMI was found as $22.40 \pm 3.49 \mathrm{~kg} / \mathrm{m}^{2}$ (min: $14.69 \mathrm{~kg} / \mathrm{m}^{2}$, max: $39.54 \mathrm{~kg} / \mathrm{m}^{2}$ ). The most common group of the BMI classification of this study was the "normal weight" (646 participants) with the rate of $72.3 \%$. The rate of overweight participants was found as $15.1 \%$. Similarly, $9.6 \%$ of the participants were taken placed in underweight groups. Class I obese groups had $2.3 \%$ of rate. On the other hand Class II groups and Class III groups had lower rates, $0.7 \%$ and $0.0 \%$, respectively. In our study all of the three obese groups defined by WHO (see Figure 1) were transformed as a single group. Depending on this new BMI classification total obese rate (Class I+Class II+Class III) was found surprisingly low rate as 3.0\% in our study. When the literature is analyzed, opposite results might be found generally. For example, Cameron et al (2003) reported that $20.8 \%$ of population in Australia was obese $(n=11.247$; age $=25+)$. Luo et al found out that the prevalence of obesity in a Canadian sample $(n=18.668$; age $=20+)$ was $22.7 \%$. On the other hand Bassett et al (2008) and Prentice (2006) performed meta-analyzes on obesity prevalence in different countries in the world. Obesity prevalence in different countries is demonstrated and compared with our study in Table 12.

Table 12. Obesity prevalence in different countries and comparison of our study

\begin{tabular}{|c|c|c|c|c|c|c|}
\hline Country & Researchers & Age & $\begin{array}{c}\text { Obesity } \\
\text { rate } \\
\text { female) }\end{array}$ & $\begin{array}{c}\text { Obesity } \\
\text { rate } \\
(\mathrm{male})\end{array}$ & $\begin{array}{c}\text { General } \\
\text { obesity } \\
\text { rate }\end{array}$ & $\begin{array}{c}\text { Compared our study } \\
\text { Female: } 1.1 \% \\
\text { Male: } 4.9 \% \\
\text { Total: } 3 \% * * *\end{array}$ \\
\hline Philippines & Nishida\&Mucavele* & $20+$ & $4 \%$ & $3 \%$ & $2.0 \%$ & Similar \\
\hline Japan & Nishida\&Mucavele* & $15+$ & $3 \%$ & $3 \%$ & $3.0 \%$ & Similar \\
\hline China & Nishida\&Mucavele* & $20+$ & $4 \%$ & $2 \%$ & $3.0 \%$ & Similar \\
\hline Singapore & Nishida\&Mucavele* & $18+$ & $7 \%$ & $5 \%$ & $6.0 \%$ & Similar \\
\hline Switzerland & Eichholzer et al** & $15+$ & N.A & N.A & $8.0 \%$ & Partly similar \\
\hline Netherland & Schokker et al** & $20+$ & $7.7 \%$ & $8.5 \%$ & $8.1 \%$ & Partly similar \\
\hline Italy & Gallus et al** & $18+$ & $8.9 \%$ & $7.4 \%$ & $8.2 \%$ & Partly similar \\
\hline Sweden & Sundquist et al** & $16+$ & $9.3 \%$ & $9.6 \%$ & $9.4 \%$ & Partly similar \\
\hline Morocco & Nishida\&Mucavele* & $18+$ & $16 \%$ & $4 \%$ & $10.0 \%$ & Similar \\
\hline Iran & Nishida\&Mucavele* & $15+$ & $14 \%$ & $6 \%$ & $10.0 \%$ & Partly similar \\
\hline France & INSERM $* *$ & $15+$ & N.A. & N.A. & $11.0 \%$ & Higher \\
\hline
\end{tabular}


Uluöz, E. (2016). Overweightness and obesity prevalence among university students in 2015-2016 educational season. Journal of Human Sciences, 13(3), 5884-5900. doi:10.14687/jhs.v13i3.4293

\begin{tabular}{|c|c|c|c|c|c|c|}
\hline Germany & $\begin{array}{c}\text { Federal Statistical } \\
\text { Office, Germany } * *\end{array}$ & $18+$ & N.A. & N. A. & $12.1 \%$ & Higher \\
\hline Denmark & Bendixen et al** & $16+$ & $12.5 \%$ & $11.8 \%$ & $12.2 \%$ & Higher \\
\hline Spain & Martinez et al ${ }^{* *}$ & $16+$ & 13.6 & $11.9 \%$ & $12.8 \%$ & Higher \\
\hline Finland & Tikkinen et al** & $18+$ & 13.2 & $13.5 \%$ & $13.3 \%$ & Higher \\
\hline Canada & Vanasse et al** & $20+$ & N.A. & N.A. & $15.2 \%$ & Higher \\
\hline Australia & Brown et al** & $18+$ & $15.8 \%$ & $16.6 \%$ & $16.2 \%$ & Higher \\
\hline Saudi Arabia & Nishida\&Mucavele* & $18+$ & $20 \%$ & $13 \%$ & $17.0 \%$ & Higher \\
\hline Ireland & McCarthy et al ${ }^{* *}$ & $18+$ & $16 \%$ & $20 \%$ & $18.0 \%$ & Higher \\
\hline USA & Ni et al** & $20+$ & N.A. & N.A. & $23.9 \%$ & Higher \\
\hline Egypt & Nishida\&Mucavele* & $18+$ & $33 \%$ & $13 \%$ & $25.0 \%$ & Higher \\
\hline Bahrain & Nishida\&Mucavele* & $19+$ & $34 \%$ & $23 \%$ & $29.0 \%$ & Higher \\
\hline
\end{tabular}

N.A. (not available)

*quoted by Prentice (2006)

** quoted by Bassett et al (2008)

$* * *$ BMI was calculated from self-reported height and weight. Obesity $\left(\mathrm{BMI} \geq 30 \mathrm{~kg} / \mathrm{m}^{2}\right)$

Table 12 demonstrates that our result of obesity prevalence is similar to Philippines, Japan, China and Singapore population where place in Asia like Turkey. In contrast with the similarity, France, Germany, Denmark, Spain, Finland, Canada, Australia, Saudi Arabia, Ireland, United States, Egypt, Bahrain populations have higher obesity rates than Turkey. Both similarity of our results to Asian population and opposition of the result of developed countries have higher rates than our result might be accepted a usual status. Living style, eating habits and various geographical conditions might cause these differences related to obesity prevalence rates.

Table 13. Obesity prevalence in Turkey and comparison of our study

\begin{tabular}{|c|c|c|c|c|c|c|}
\hline $\begin{array}{c}\text { Name of } \\
\text { study/city/sample }\end{array}$ & Researchers & Age & $\begin{array}{l}\text { Obesity } \\
\text { rate } \\
\text { (female) }\end{array}$ & $\begin{array}{c}\text { Obesity } \\
\text { rate } \\
\text { (male) }\end{array}$ & $\begin{array}{c}\text { General } \\
\text { obesity } \\
\text { rate }\end{array}$ & $\begin{array}{c}\text { Compare } \\
\text { our study } \\
\text { Female: } 1.1 \% \\
\text { Male: } 4.9 \% \\
\text { Total: } 3 \%{ }^{* * *}\end{array}$ \\
\hline $\begin{array}{c}\text { TEKHARF } \\
\text { (General } \\
\text { population) }\end{array}$ & $\begin{array}{c}\text { Onat et al, } \\
1999\end{array}$ & $<30$ & $43.0 \%$ & $21.1 \%$ & $32.0 \%$ & $\begin{array}{c}\text { Extremely } \\
\text { higher }\end{array}$ \\
\hline $\begin{array}{l}\text { TOHTA } \\
\text { (General } \\
\text { population) }\end{array}$ & $\begin{array}{l}\text { Hatemi et al } \\
\text { (2003) }\end{array}$ & $20+$ & $35.4 \%$ & $19.6 \%$ & $27.5 \%$ & $\begin{array}{l}\text { Extremely } \\
\text { higher }\end{array}$ \\
\hline $\begin{array}{l}\text { TURDEP } \\
\text { (General } \\
\text { population) }\end{array}$ & $\begin{array}{l}\text { Satman et al } \\
(2002)\end{array}$ & $20+$ & $29.9 \%$ & $12.9 \%$ & $22.3 \%$ & $\begin{array}{l}\text { Extremely } \\
\text { higher }\end{array}$ \\
\hline $\begin{array}{l}\text { TOAD } \\
\text { (General } \\
\text { population) }\end{array}$ & $\begin{array}{c}\text { Bağriaçık et al } \\
\text { (2009) }\end{array}$ & $20+$ & $36.9 \%$ & $21.8 \%$ & $29.3 \%$ & $\begin{array}{l}\text { Extremely } \\
\text { higher }\end{array}$ \\
\hline $\begin{array}{l}\text { Kocaeli City } \\
\text { sample } \\
\text { (General } \\
\text { population) }\end{array}$ & $\begin{array}{l}\text { Aladağ et al } \\
\quad(2007)\end{array}$ & $18+$ & $29.2 \%$ & $26.9 \%$ & $28.0 \%$ & $\begin{array}{l}\text { Extremely } \\
\text { higher }\end{array}$ \\
\hline $\begin{array}{l}\text { Ankara City } \\
\text { sample } \\
\text { (University } \\
\text { students) }\end{array}$ & $\begin{array}{c}\text { Avşar et al } \\
(2013)\end{array}$ & $17-21$ & N.A. & N.A. & $3.6 \%$ & Similar \\
\hline
\end{tabular}


Uluöz, E. (2016). Overweightness and obesity prevalence among university students in 2015-2016 educational season. Journal of Human Sciences, 13(3), 5884-5900. doi:10.14687/ihs.v13i3.4293

\begin{tabular}{|c|c|c|c|c|c|c|}
\hline $\begin{array}{c}\text { Erzurum City } \\
\text { sample (University } \\
\text { students) }\end{array}$ & $\begin{array}{c}\text { Vançelik et al } \\
(2006)\end{array}$ & $21.6 \pm 1.9$ & $0.2 \%$ & $1.0 \%$ & $\mathbf{0 . 6 \%}$ & Lower \\
\hline $\begin{array}{c}\text { Kayseri City } \\
\text { Sample } \\
\text { (University } \\
\text { students) }\end{array}$ & $\begin{array}{c}\text { Soyuer et al } \\
(2010)\end{array}$ & $20.68 \pm 3.15$ & $7.4 \%$ & $12.2 \%$ & $8.5 \%$ & Higher \\
\hline $\begin{array}{c}\text { Ankara City } \\
\text { sample (University } \\
\text { students) }\end{array}$ & $\begin{array}{c}\text { Ergün\&Erten } \\
(2004)\end{array}$ & $18-22$ & $0.5 \%$ & $2.4 \%$ & $1.5 \%$ & Lower \\
\hline
\end{tabular}

As the Table 13 is observed, it can be seen the differences of the rate of obesity among the previous studies and our study. We found out the general obesity rate as 3.0\%. Avşar et al (2013) reported a similar result with our study. On the other hand, Vançelik et al (2006) and Ergün\&Erten (2004) found a lower obesity rate compared with Avşar et al (2013) and our study. Although, there is a small amount of differences between results of the four studies, the rate of obesity in TEKHARF, TOHTA, TURDEP, TOAD and Kocaeli City sample studies have been extremely higher than the four studies performed among university students. It might be derived from these sharp differences due to large (TEKHARF, TOHTA, TURDEP, TOAD and Kocaeli City sample ) and narrow (Avşar et al., 2013; Vançelik et al., 2006; Soyuer et al.,2010; Ergün\&Erten, 2004 and our study) age ranges in all studies. Also, while all university students have almost the same living condition, there are many various reasons related to obesity such as gender, age, socio economic level, lifestyle, etc. in normal population affected overweightness and obesity. Table 14 shows the mean of the BMI scores of male and female university students from 22 different countries in the world reported by Wardle et al (2006), various university students from Turkey and the result of our study.

Table 14. BMI of university students reported by Wardle et al (2006) (from 22 countries) and comparing with Turkish Students and our samples

\begin{tabular}{|l|c|c|c|c|}
\hline Country & $\begin{array}{c}\text { Female } \\
\left(\mathrm{kg} / \mathrm{m}^{2}\right)\end{array}$ & $\begin{array}{c}\text { Our study (Female) } \\
\mathrm{BMI}=21.01 \mathrm{~kg} / \mathrm{m}^{2}\end{array}$ & $\begin{array}{c}\text { Male } \\
\left(\mathrm{kg} / \mathrm{m}^{2}\right)\end{array}$ & $\begin{array}{c}\text { Our study (Male) } \\
\mathrm{BMI}=23.80 \mathrm{~kg} / \mathrm{m}^{2}\end{array}$ \\
\hline Belgium & 20.9 & Lower & 22.1 & Lower \\
\hline England & 20.9 & Lower & 22.7 & Lower \\
\hline France & 20.6 & Lower & 21.9 & Lower \\
\hline Germany & 20.9 & Lower & 22.8 & Lower \\
\hline Iceland & 22.1 & Higher & 23.6 & Lower \\
\hline Ireland & 21.3 & Higher & 22.3 & Lower \\
\hline Netherlands & 21.5 & Higher & 21.9 & Lower \\
\hline United States & 22.6 & Higher & 24.3 & Higher \\
\hline Bulgaria & 19.9 & Lower & 23.1 & Lower \\
\hline Hungary & 20.4 & Lower & 22.1 & Lower \\
\hline Poland & 20.1 & Lower & 22.8 & Lower \\
\hline Romania & 20.0 & Lower & 22.3 & Lower \\
\hline Slovakia & 20.4 & Lower & 23.0 & Lower \\
\hline Greece & 20.8 & Lower & 23.4 & Lower \\
\hline Italy & 20.0 & Lower & 22.2 & Lower \\
\hline Portugal & 21.1 & Higher & 22.9 & Lower \\
\hline Spain & 21.1 & Higher & 23.2 & Lower \\
\hline Japan & 20.5 & Lower & 21.5 & Lower \\
\hline Korea & 19.3 & Lower & 20.7 & Lower \\
\hline Thailand & 19.6 & Lower & 20.5 & Lower \\
\hline
\end{tabular}


Uluöz, E. (2016). Overweightness and obesity prevalence among university students in 2015-2016 educational season. Journal of Human Sciences, 13(3), 5884-5900. doi:10.14687/ihs.v13i3.4293

\begin{tabular}{|l|c|c|c|c|}
\hline Columbia & 20.6 & Lower & 21.8 & Lower \\
\hline Venezuela & 21.0 & Lower & 23.6 & Lower \\
\hline Total & 20.7 & Lower & 22.4 & Lower \\
\hline \multicolumn{5}{|c|}{ BMI means of Turkish university students reported by previous studies } \\
\hline $\begin{array}{l}\text { Mazıcıŏlu\&Öztürk } \\
(2003)\end{array}$ & 20.77 & Lower & 22.70 & lower \\
\hline $\begin{array}{l}\text { Vançelik et al } \\
(2006)\end{array}$ & 20.70 & lower & 22.60 & lower \\
\hline Altın (2015) & 26.23 & Higher & 23.43 & lower \\
\hline
\end{tabular}

Surprisingly, the mean BMI score of male in our study are higher than both the mean BMI scores of male in 22 different countries reported by Wardle et al (2006) and all of the previous studies performed on male university students in Turkey. On the other hand our result is lower only United States result reported by Wardle et al (2006). Because numerous studies have been reported that the prevalence of obesity among all age groups in United States have been extremely higher than the other countries (Filozof et al., 2001; Janssen et al., 2005; Monteiro et al., 2004; Ogden et al., 2006), it might be accepted as usual (being the highest rate in American male population in comparing of Table 14). Another comparison in table 14 is the mean BMI scores of females among the various populations. In accordance with the comparison, Korean female university students have the lowest BMI mean with 19.3\%. Conversely, the female students in United States have the highest BMI mean among the all other countries. It have been demonstrated that American University students have the highest BMI scores without gender differences. It might be considered a remarkable point of this compassion in Table 14 that the result of our study in male group is having the second highest BMI scores $(23.80 \pm 3.40)$ among the all other male groups after the American students. Although the result seems as if an unexpected situation at first, however, in fact this might be usual because of the similarity of the other studies results which have been performed on male university student populations in Turkey in Table 14 (Altın, 2015; Mazıcıoğlu\&Öztürk, 2003; Vançelik et al., 2006). In addition to this comparison performed in male and female groups in their own gender, we also compared the mean of BMI scores of our participants in terms of opposite gender. We found that the mean of BMI of male statistically significant higher than female participants' (see table 5). Parallel to our findings, Wardle et al (2006), Mazıcıoğlu\&Öztürk (2003) and Vançelik et al. (2006) reported that the mean of BMI of males higher than female participants'. In contrast with this specific result for female age group (university students), numerous studies reported that BMI scores of females or obesity rates clearly higher than males (see Table 12). These differences might be explained that physical niceness, attractiveness and cosmetic perfection are more especially important for females in the twenties ages than the older ages compared with males.

We not surprisingly found that the mean of BMI of participants whom being an obese person in own family statistically significant higher than not being group. In accordance with this result, we also found highly significant difference among BMI classification groups for having an obese person in own family or not groups (see Table 9). As numerous studies have clearly focused that there is an extremely strong relationship between obesity and heredity or genetic factors (Bulik et al., 2003; Hartz et al., 1977; Hellström\&Reynisdottir, 2000; Scuteri et al., 2007), our findings might be accepted usual. Numerous studies have focused physical activities and the hindering factors related to physical activities among university students and reported a relationship BMI and doing physical activity. (Aslan et al., 2007; Burke et al., 2006; Haase et al., 2004; Irwin, 2007; Özcan\&Bozhüyük, 2016; Savc1 et al., 2006; Türkmen et al., 2016; Uluöz et al., 2016). We also found that there is no statistically significant difference between the mean BMI of doing physical activity or not groups. On the other hand, there was a highly significant difference among BMI classification groups for doing physical activity or not groups. Overweight group had the highest 
Uluöz, E. (2016). Overweightness and obesity prevalence among university students in 2015-2016 educational season. Journal of Human Sciences, 13(3), 5884-5900. doi:10.14687/ihs.v13i3.4293

rate for doing physical activity $(61,5) \%$. Contrarily, obese groups had the lowest rate $(33 \%)$. This result might be explained that obese peoples may unconsciously concede their own physical condition by means of social bias (Janssen et al., 2004; Puhl\&Brownell, 2001; Y1lmaz, C.Y.\&Dinç Z.F., 2010)

\section{Conclusions and Recommendations}

In conclusion, obesity is the most common health problem for humanity. In fact, obesity is a multi-factor chronic disease which reduces quality of life. It is one of the diseases increasing rapidly and affecting individuals and societies in Turkey like all over the world. For this reason policies are being developed all over the world in the fight against obesity for all kind of population (all age groups and genders). In accordance with this situation, some recommendations should be given as below;

- Ensuring political demands and resilience at the national and local level and implementation against obesity

- More strict measures taken by the government to reduce obesity rates in society

- Informing and awareness of community on obesity

- Informing adequate and balanced nutrition

- Informing benefits of regular physical activity against obesity

- Increasing the number of hours of physical education and sports lessons in schools as much as possible. The processing of these courses must be inspected strongly

- Selling of fast food product in all school from pre-school to university must be forbidden by The Governments.

- Organizing social responsibility projects to prevent obese individuals from being excluded from society

- Increasing physical activity possibilities for people in all condition by Governments

- All media facilities should be used against obesity (TV, Radio, Press, Social Media).

\section{References}

Aladağ, N., Ciğerli, Ö., Topsever, P., Topall, R., Görpelioğlu, S., \& Filiz, T. M. (2007). Değirmendere aile hekimliği polikliniğine başvuran erişkin hastalarda obezite sıklı̆̆ ve eşlik eden hastalıklarla ilişkisi: bir olgu kontrol çalışması. Türkiye Aile Hekimliŭgi Dergisi, 7(3), 117121.

Altın, M. (2015) Üniversite öğrencilerinin beslenme alışkanlıklanı ve obezite ilişkisi.sportif bakış. Spor ve Eğitim Bilimleri Dergisi, 2 (2), 87-96.

Aslan, U. B., Livanelioğlu, A., \& Aslan, Ş. (2007). Fiziksel aktivite düzeyinin üniversite öğrencilerinde iki farklı yöntemle değerlendirilmesi. Fisyoterapi Rebabilitasyon, 18(1), 11-19.

Avenell, A., Broom, J., Brown, T. J., Poobalan, A., Aucott, L., Stearns, S. C., ... \& Grant, A. M. (2004). Systematic review of the long-term effects and economic consequences of treatments for obesity and implications for health improvement. Health Technology Assessment (Winchester, England), 8(21), iii-iv.

Avşar, P., Kazan, E. E., \& Pınar, G. (2013). Üniversite öğrencilerinin beslenme alışkanlıkları ile obezite ve kronik hastalıklara ilişkin risk faktörlerinin incelenmesi. Yildirim Beyaz̧it Üniversitesi Hemsirelike E-Dergisi, 1(1).

Bagriacik, N., Onat, H., Ilhan, B., Tarakci, T., Oşar, Z., Ozyazar, M., ... \& Yildiz, G. (2009). Obesity profile in Turkey. International Journal of Diabetes and Metabolism, 17, 5-8.

Bassett, D. R., Pucher, J., Buehler, R., Thompson, D. L., \& Crouter, S. E. (2008). Walking, cycling, and obesity rates in Europe, North America, and Australia. J Phys Act Health, 5(6), 795-814. 
Uluöz, E. (2016). Overweightness and obesity prevalence among university students in 2015-2016 educational season. Journal of Human Sciences, 13(3), 5884-5900. doi:10.14687/jhs.v13i3.4293

Bendixen, H., Holst, C., Sørensen, T. I., Raben, A., Bartels, E. M., \& Astrup, A. (2004). Major increase in prevalence of overweight and obesity between 1987 and 2001 among Danish adults. Obesity Research, 12(9), 1464-1472.

Brown, A., \& Siahpush, M. (2007). Risk factors for overweight and obesity: results from the 2001 National Health Survey. Public Health, 121(8), 603-613.

Bulik, C. M., Sullivan, P. F., \& Kendler, K. S. (2003). Genetic and environmental contributions to obesity and binge eating. International Journal of Eating Disorders, 33(3), 293-298.

Burke, S. M., Carron, A. V., \& Eys, M. A. (2006). Physical activity context: Preferences of university students. Psychology of Sport and Exercise, 7(1), 1-13.

Büyüköztürk, S., Kiliç Çakmak, E., Akgün, Ö. E., Karadeniz, S., \& Demirel, F. (2012). Bilimsel Arastirma Yöntemleri (18. Baski). Ankara: Pegem Akademi Yayimcilik.

Cameron, A. J., Welborn, T. A., Zimmet, P. Z., Dunstan, D. W., Owen, N., Salmon, J., ... \& Shaw, J. E. (2003). Overweight and obesity in Australia: the 1999-2000 Australian diabetes, obesity and lifestyle study (AusDiab). Medical Journal of Australia, 178(9), 427-432.

Cancello, R., \& Clement, K. (2006). Review article: Is obesity an inflammatory illness? Role of lowgrade inflammation and macrophage infiltration in human white adipose tissue. BJOG: $A n$ International Journal of Obstetrics of Gynaecology, 113(10), 1141-1147.

Cheung, N., \& Wong, T. Y. (2007). Obesity and eye diseases. Survey of Ophthalmology, 52(2), 180195.

Eckel, R. H., Barouch, W. W., \& Ershow, A. G. (2002). Report of the national heart, lung, and blood institute-national institute of diabetes and digestive and kidney diseases working group on the pathophysiology of obesity-associated cardiovascular disease. Circulation, 105(24), 2923-2928.

Eichholzer, M., Bernasconi, F., Jordan, P., \& Gutzwiller, F. (2005). [Nutrition in Switzerland 2002-results of the Swiss Health Survey]. Praxis, 94(44), 1713-1721.

Ergün, A., \& Erten, S. F. (2004). Öğrencilerde vücut kitle indeksi ve bel çevresi değerlerinin incelenmesi. Ankara Üniversitesi Tap Fakültesi Mecmuasi, 57(02).

Federal Statistical Office-Germany. Body measures of the population by age groups, results from the micro-census in April 1999 [in German].

Filozof, C., Gonzalez, C., Sereday, M., Mazza, C., \& Braguinsky, J. (2001). Obesity prevalence and trends in Latin-American countries. Obesity Reviews, 2(2), 99-106.

Fogelholm, M. (2010). Physical activity, fitness and fatness: relations to mortality, morbidity and disease risk factors. A systematic review. Obesity Reviews, 11(3), 202-221.

Gallus, S., Colombo, P., Scarpino, V., Zuccaro, P., Negri, E., Apolone, G., \& La Vecchia, C. (2006). Overweight and obesity in Italian adults 2004, and an overview of trends since 1983. European Journal of Clinical Nutrition, 60(10), 1174-1179.

Haase, A., Steptoe, A., Sallis, J. F., \& Wardle, J. (2004). Leisure-time physical activity in university students from 23 countries: associations with health beliefs, risk awareness, and national economic development. Preventive Medicine, 39(1), 182-190.

Hartz, A., Giefer, E., \& Rimm, A. A. (1977). Relative importance of the effect of family environment and heredity on obesity. Annals of Human Genetics, 41(2), 185-193.

Hatemi, H., Turan, N., Arık, N., \& Yumuk, V. (2002). Türkiye obezite ve hipertansiyon taramas1 sonuçları (TOHTA). Endokrinolojide Yönelişler Dergisi, 11(1), 1-16.

Hellström, L., \& Reynisdottir, S. (2000). Influence of heredity for obesity on adipocyte lipolysis in lean and obese subjects. International Journal of Obesity of Related Metabolic Disorders, 24(3).

Hersoug, L. G., \& Linneberg, A. (2007). The link between the epidemics of obesity and allergic diseases: does obesity induce decreased immune tolerance?. Allergy, 62(10), 1205-1213.

INSERM (Intitute Nationale de la Sante Et de la Researche Medicale). ObEpi, (2003). Obesity and Overweight in France: Epidemiologic Survey Performed in a Representative Sample of the French Adult Population [in French]. Neuilly-sur-Seine: Institute Roche de L'Obesite, Sofres. 
Uluöz, E. (2016). Overweightness and obesity prevalence among university students in 2015-2016 educational season. Journal of Human Sciences, 13(3), 5884-5900. doi:10.14687/jhs.v13i3.4293

Irwin, J. D. (2007). The prevalence of physical activity maintenance in a sample of university students: a longitudinal study. Journal of American College Health, 56(1), 37-42.

Janssen, I., Craig, W. M., Boyce, W. F., \& Pickett, W. (2004). Associations between overweight and obesity with bullying behaviors in school-aged children. Pediatrics, 113(5), 1187-1194.

Janssen, I., Katzmarzyk, P. T., Boyce, W. F., Vereecken, C., Mulvihill, C., Roberts, C., ... \& Pickett, W. (2005). Comparison of overweight and obesity prevalence in school-aged youth from 34 countries and their relationships with physical activity and dietary patterns. Obesity Reviews, 6(2), 123-132.

Kalan, I., \& Yeşil, Y. (2010). Obezite ile ilişkili kronik hastalıklar. Diyabet ve Obezite, 78.

Martinez, J. A., Moreno, B., \& Martinez-González, M. A. (2004). Prevalence of obesity in Spain. Obesity Reviews, 5(3), 171-172.

Mazicioglu, M. M., \& Ozturk, A. (2003). Dietary habits and influencing factors in university students at 3rd and 4th grades. Erciyes Tip Dergisi, 25, 172-178.

McCarthy, S. N., Gibney, M. J., Flynn, A., \& Irish, U. N. A. (2002). Overweight, obesity and physical activity levels in Irish adults: evidence from the North/South Ireland food consumption survey. The Proceedings of the Nutrition Society, 61(1), 3.

Mokdad, A. H., Ford, E. S., Bowman, B. A., Dietz, W. H., Vinicor, F., Bales, V. S., \& Marks, J. S. (2003). Prevalence of obesity, diabetes, and obesity-related health risk factors, 2001. Jama, 289(1), 76-79.

Monteiro, C. A., Moura, E. C., Conde, W. L., \& Popkin, B. M. (2004). Socioeconomic status and obesity in adult populations of developing countries: a review. Bulletin of the World Health Organization, 82(12), 940-946.

Moreno, L. A., \& Rodríguez, G. (2007). Dietary risk factors for development of childhood obesity. Current Opinion in Clinical Nutrition of Metabolic Care, 10(3), 336-341.

Must, A., Spadano, J., Coakley, E. H., Field, A. E., Colditz, G., \& Dietz, W. H. (1999). The disease burden associated with overweight and obesity. Jama, 282(16), 1523-1529.

NIH (National Institutes of Health). What Are the Health Risks of Overweight and Obesity? https://www.nhlbi.nih.gov/health/health-topics/topics/obe/risks Updated: July 13, 2012) (Accessed 24.10.2016)

Ni H, Schiller J, Hao C, Cohen RA, Barnes P. Early release of selected estimates based on data from the 2002 National Health Interview Survey. National Center for Health Statistics. http://www.cdc.gov/nchs/nhis/index.htm (Accessed 24.10.2016)

Nishida, C., \& Mucavele, P. (2005). Monitoring the rapidly emerging public health problem of overweight and obesity: the WHO Global Database on Body Mass Index. SCN News, (29), $5-11$.

Ogden, C. L., Carroll, M. D., Curtin, L. R., McDowell, M. A., Tabak, C. J., \& Flegal, K. M. (2006). Prevalence of overweight and obesity in the United States, 1999-2004. Jama, 295(13), 15491555.

Onat, A., Yıldırım, B., Çetinkaya, A., Aksu, H., Keleş, İ., Uslu, N., ... \& Sansoy, V. (1999). Erişkinlerimizde obezite ve santral obezite göstergeleri ve ilişkileri: 1990-98'de Düşündürücü Obezite Artışı erkeklerde daha belirgin. Türk Kardiyoloji Arşivi, 27, 209-17.

Özcan, S., \& Bozhüyük, A. (2016). Healthy life behaviors of the health science students of Cukurova University. Cukurova Medical Journal, 41(4), 664-674.

Özdel, O., Sözeri-Varma, G., Fenkçi, S., Değirmenci, T., Karadağ, F., Kalkan-Oğuzhanoğlu, N., \& Ateşçi, F. (2011). Obez Kadınlarda Psikiyatrik Tanı Sıklı̆̆1. Klinike Psikizyatri Dergisi, 14(4).

Prentice, A. M. (2006). The emerging epidemic of obesity in developing countries. International Journal of Epidemiology, 35(1), 93-99.

Puhl, R., \& Brownell, K. D. (2001). Bias, discrimination, and obesity. Obesity Research, 9(12), 788805. 
Uluöz, E. (2016). Overweightness and obesity prevalence among university students in 2015-2016 educational season. Journal of Human Sciences, 13(3), 5884-5900. doi:10.14687/jhs.v13i3.4293

Satman, I., Dinccag, N., Karsidag, K., Sengul, A., Salman, F., Sargin, M., ... \& Ozcan, C. (2000). Epidemiology of diabetes and obesity in Turkey. Diabetes Research and Clinical Practice, $50,142$.

Savc1, S., Öztürk, M., Arrkan, H., İnal İnce, D., \& Tokgözoğlu, L. (2006). Üniversite öğrencilerinin fiziksel aktivite düzeyi. Türk Kardiyoloji Arşivi, 34(3), 166-172.

Schokker, D. F., Visscher, T. L. S., Nooyens, A. C. J., Van Baak, M. A., \& Seidell, J. C. (2007). Prevalence of overweight and obesity in the Netherlands. Obesity Reviews, 8(2), 101-107.

Scuteri, A., Sanna, S., Chen, W. M., Uda, M., Albai, G., Strait, J., ... \& Dei, M. (2007). Genome-wide association scan shows genetic variants in the FTO gene are associated with obesity-related traits. PLoS Genet, 3(7), e115.

Soyuer, F., Ünalan, D., \& Elmalı, F. (2010). Normal ağırlıklı ve obez üniversite öğrencilerinde fiziksel aktivite. Uluslararası Insan Bilimleri Dergisi, 2, 862-872.

Steyn, K., Bourne, L., Jooste, P., Fourie, J. M., Rossouw, K., \& Lombard, C. (1998). Anthropometric profile of a black population of the Cape Peninsula in South Africa. East African Medical Journal, 75(1), 35-40.

Sundquist, K., Qvist, J., Johansson, S. E., \& Sundquist, J. (2004). Increasing trends of obesity in Sweden between 1996/97 and 2000/01. International Journal of Obesity, 28(2), 254-261.

TC Sağlık Bakanlığı, Sağlık Hizmetleri Genel Müdürlügü. (2010). Türkiye Sağlıklı Beslenme ve Hareketli Hayat Program1 (2010-2014). Kuban Matbaachlk. Yaymollk,, Ankara.

Tikkinen, K. A., Auvinen, A., Huhtala, H., \& Tammela, T. L. (2006). Nocturia and obesity: a population-based study in Finland. American Joumal of Epidemiology, 163(11), 1003-1011.

Türkmen, M., Kul, M., Ocalan, M., Ozkan, A., \& Bozkus, T. (2013). Determination of the relationship between physical activity levels and healthy life-style behaviors of university students. Australian Journal of Basic and Applied Sciences, 7(10), 507-512.

Uluöz, E., Yılmaz C.Y., Dinç Z.F., Kavasoğlu İ., Avluk A.İ. (2016). Determination of University Students' Situation in Undertaking Physical Activities and Factors Hindering Their Participation in Physical Activities. World Applied Sciences Journal 34 (2): 245-249.

Vanasse, A., Demers, M., Hemiari, A., \& Courteau, J. (2006). Obesity in Canada: where and how many?. International Journal of Obesity, 30(4), 677-683.

Vançelik, S., Önal, S. G., \& Güraksin, A. (2006). Atatürk Üniversitesi öğrencilerinde beden ağırlı̆g1 durumu ve ilişkili bazı faktörler. TAF Preventive Medicine Bulletin, 5(2), 72-82.

Wang, Y., \& Beydoun, M. A. (2007). The obesity epidemic in the United States-gender, age, socioeconomic, racial/ethnic, and geographic characteristics: a systematic review and metaregression analysis. Epidemiologic Reviews, 29(1), 6-28.

Wardle, J., Haase, A. M., \& Steptoe, A. (2006). Body image and weight control in young adults: international comparisons in university students from 22 countries. International Journal of Obesity, 30(4), 644-651.

WHO Media Center. (2016). Obesity and overweight. Updated June 2016 http://www.who.int/mediacentre/factsheets/fs311/en/) (Accessed 24.10.2016)

WHO. (2016). Ten Facts on Obesity. http://www.who.int/features/factfiles/obesity/facts/en/ (Accessed 24.10.2016)

World Health Organization. (1997). Obesity: preventing and managing the global epidemic. Report of a WHO Consultation presented at: the World Health Organization; June3-5, 1997; Geneva, Switzerland. Geneva, Switzerland: WHO.

World Health Organization. (1998). Prevention and Management of the Global Epidemic of Obesity. Report of the WHO Consultation on Obesity. WHO: Geneva (No. 894). Technical Report Series.

Yilmaz, C. Y., \& Dinç, Z. F. (2010). Beden eğitimi ve spor yüksekokulu'nda öğrenim gören genç kadin ve erkek öğrencilerin kilofobi düzeylerinin karşılaştırılması. Spormetre Beden Eğitimi ve Spor Bilimleri Dergisi, VIII (1) 29-34 